\title{
Does a Stronger Dollar Erode the Profitability of U.S. Firms?
}

YiLi Chien, Senior Economist

Paul Morris, Research Associate

rom the second quarter of 2014 to the first quarter of 2016, the trade-weighted U.S. dollar appreciated more than 20 percent. Such a large and swift appreciation creates some concerns regarding the health of the U.S. economy. One major concern is the profitability of U.S. firms, especially those that rely heavily on foreign sales. In today's global economy, many U.S. firms sell significant quantities in foreign markets. For example, in 2015, 44.3 percent of the revenue of S\&P 500 firms came from foreign markets. ${ }^{1}$ When the dollar appreciates, U.S. goods become more expensive to foreigners, potentially reducing sales and hurting the exporting sector of the U.S. economy. A higher exchange rate even reduces dollardenominated foreign revenues of firms that both produce and sell in foreign countries. Hence, the sharp appreciation of the dollar that started in mid-2014 could erode the profitability of U.S. firms significantly.

\section{U.S. firms have adjusted well in response to the recent appreciation of the dollar.}

This essay investigates the recent effects of the strong dollar on the market value of U.S. firms. Our strategy is simple: We calculate the differential stock market return between firms with a large share of foreign sales and firms with a low share of foreign sales. Comparing these two portfolios should wash out any factor that affects overall stock market returns. The return differential is therefore a market estimate of the impact of the recent appreciation on the profitability of firms that depend more heavily on foreign markets. ${ }^{2}$

We use Compustat data from 2013 to 2016 for 2,992 publicly traded U.S. firms, which we divide into two groups: firms whose foreign sales are at least 50 percent of total sales and firms whose foreign sales are less than 50 percent of total sales. We then form a weighted investment portfolio for each group. The portfolio weight is based on the

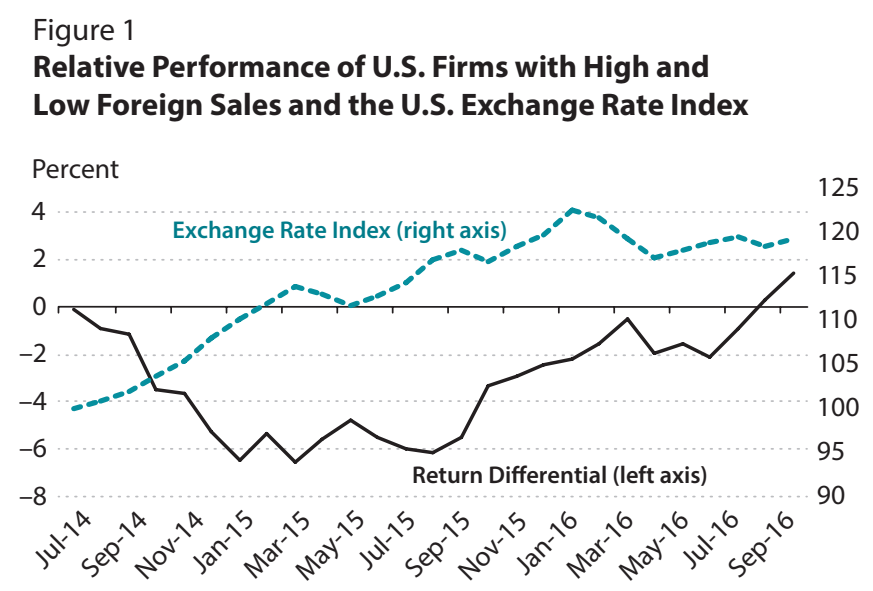

SOURCE: Compustat, Board of Governors of the Federal Reserve System, and authors' calculations.

Figure 2

Relative Performance of U.S. Manufacturing Firms with High and Low Foreign Sales and the U.S. Exchange Rate Index

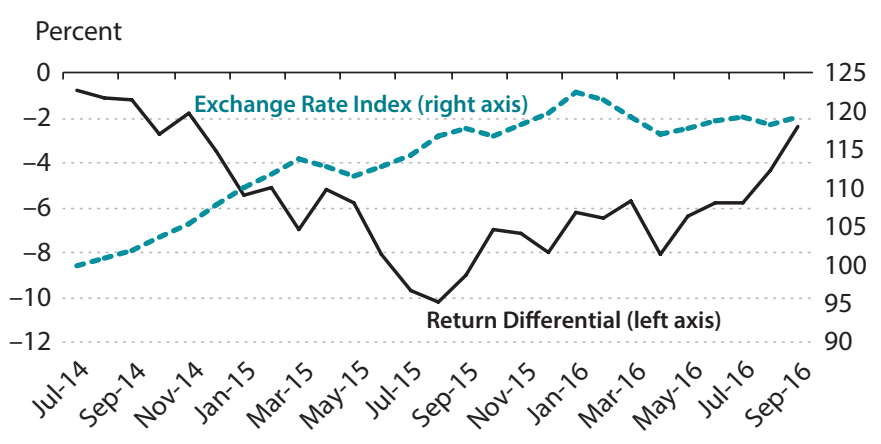

SOURCE: Compustat, Board of Governors of the Federal Reserve System, and authors' calculations.

market values of firms in 2013. We exclude petroleum manufacturing firms from the analysis because their returns were heavily reduced by the sharp decline in oil prices during this period. We also exclude financial firms from our analysis because non-financial firms have greater exposure to exchange rate risks relative to financial firms. 
Figure 1 shows the cumulative return differential (solid line) between the high foreign sales and the low foreign sales portfolios from July 2014 to September 2016 and the U.S. exchange rate index (dashed line) during the same period. Initially, the firms with high foreign sales experienced relatively poor returns compared with those with low foreign sales. In the first seven months, the value of the dollar increased more than 10 percent and the lowforeign-sales portfolio outperformed the high-foreign-sales portfolio by a sizable margin-over 6 percentage points. However, the effect was reversed in the second half of the sample period: The high-foreign-sales portfolio performed better than the low-foreign-sales portfolio despite the dollar appreciating another 10 percent, and its cumulative return surpassed the low-foreign-sales portfolio in August 2016. This result shows that the strong dollar eroded the market value of firms in the short run but not in the long run. In short, the strong dollar has not permanently damaged the profitability of firms with a significant amount of foreign sales.

One possible explanation pertains to the global supply chain. Firms with high foreign sales are larger and tend to be multinational. In today's global market, it is likely that they are capable of adjusting their production and sales between home and foreign countries. The adjustment could be costly and slow and, hence, not feasible in the short term. In the long term, firms could shift production and possibly focus more on the domestic market to reduce the impact on profits caused by the dollar's appreciation.

Figure 2 shows the results of the same exercise for manufacturing. The negative effect on manufacturing firms with high foreign sales is stronger and persisted longer. In
August 2015, the cumulative return differential (solid line) peaked at over 10 percent. It also recovered more slowly than that for all firms (see Figure 1). By the first quarter of 2016, while the return differential was nearly closed for all firms, it still remained near 6 percent for manufacturing firms. However, the cumulative return differential among manufacturing firms eventually begins to disappear. In the past quarter, it was only about 2 percent. Manufacturing firms may have suffered more than firms overall because of the asymmetric exposure to risk between the different types of firms: For example, manufacturing firms may be less flexible when it comes to adjusting production or market focus in response to a change in the exchange rate. Hence, the appreciation of the dollar could hurt manufacturing firms more.

Data show that the recent appreciation of the dollar starting in 2014 lowered the value of firms only in the short run. By August 2016, the value of firms with high foreign sales recovered or even surpassed the value of those with low foreign sales. This empirical result indicates that, in the long run, U.S. firms can adjust quite well in response to a large and sharp exchange rate fluctuation.

\section{Notes}

\footnotetext{
1 Silverblatt, Howard. "S\&P 500 2015 : Global Sales." S\&P Global, July 2016; https://us.spindices.com/documents/research/research-sp-500-2015-globalsales.pdf.

${ }^{2}$ There are factors other than the exchange rate that could affect firms with high foreign sales and low foreign sales differently. The recent slowdown in China and regional conflicts around the world are two examples.
} 